\title{
Upaya Meningkatkan Kosa Kata pada Anak Usia Dini melalui Permainan Tradisional Pancasila Lima Dasar
}

\author{
Buadanani $^{1 \times}$, Dadan Suryana ${ }^{1}$ \\ Pendidikan Anak Usia Dini, Universitas Negeri Padang(1) \\ DOI: $10.31004 /$ obsesi.v6i3.1951
}

\begin{abstract}
Abstrak
Kosa kata sangat penting untuk perkembangan bahasa anak, akan tetapi masih kurangnya penguasaan kosa kata ketika anak bercerita. Penelitian ini bertujuan untuk meningkatkan kosakata pada anak usia dini melalui permainan tradisional pancasila lima dasar. Sampel pada penelitian ini adalah anak kelompok B berjumlah 12 orang di TK Pembina Kandis Kabupaten Siak Propinsi Riau. Jenis penelitian ini menggunakan kualitatif yaitu penelitian tindakan kelas. Hasil penelitian pada saat pra tindakan 38,33\% masuk pada kategori belum berkembang (BB), pada siklus I nilai rata-rata sebesar 59, 16\% berada dalam kategori mulai berkembang (MB), dan pada siklus II diperoleh nilai rata-rata sebesar 77, 83\% kategori berkembang sesuai harapan (BSH). Melalui pemainan tradisional pancasila lima dasar ini anak dapat mengembangkan kemampuan penguasaan kosa kata yang bervariasi, anak akan semakin banyak mengenal kosakata baru yang belum diketahui, sehingga dapat meningkatkan kecerdasan anak dalam bahasa.
\end{abstract}

Kata Kunci : anak usia dini, kosa kata, permainan tradisonal.

\begin{abstract}
Vocabulary is very important for children's language development, but there is still a lack of vocabulary mastery when children tell stories. This study aims to increase vocabulary in early childhood through the traditional five basic Pancasila games. The sample in this study were 12 people in group B in TK Pembina Kandis, Siak Regency, Riau Province. This type of research uses qualitative, namely classroom action research. The results of this research are that at the time of pre-action $38.33 \%$ was in the undeveloped category (BB), in the first cycle the average value was $59,16 \%$ was in the starting to develop category (MB), and in the second cycle the average value was obtained. an average of $77,83 \%$ growing category as expected (BSH). Through these five basic Pancasila traditional games, children can develop varied vocabulary mastery skills, children will get to know more and more new unknown vocabulary, so that they can improve children's intelligence in language.
\end{abstract}

Keywords: early childhood, vocabulary, traditional games

Copyright (c) 2021 Buadanani, Dadan Suryana.

$\triangle$ Corresponding author :

Email Address : buadanani@gmail.com (Padang Indonesia)

Received tanggal bulan tahun, Accepted tanggal bulan tahun, Published tanggal bulan tahun 


\section{PENDAHULUAN}

Anak usia dini merupakan masa awal yang sangat penting dan paling mendasar dalam pertumbuhan dan perkembangan dalam periode awal kehidupannya. Pada periode ini merupakan periode yang fundamental pada kehidupan anak selanjutnya sampai periode akhir dari perkembangannya. Dalam Undang-undang nomor 20 Tahun 2003 bahwa anak usia dini adalah anak sejak lahir sampai anak berusia enam tahun. Menurut Suryana (2014) bahwa anak usia dini adalah sekelompok manusia yang sedang berada pada tahap pertumbuhan dan perkembangan, dan merupakan individu yang unik dan memiliki pertumbuhan dan perkembangan fisik motorik, kognitif, kereativitas, sosial emosional, bahasa dan komunikasi yang sesuai dengan tahapan perkembangan yang sedang dilalui oleh anak tersebut.

Bermain adalah tahapan anak usia dini dalam mengoptimalkan semua potensi dan perkembangan anak. sebagaimana yang diungkap oleh Suryana (2013) dengan bermain kreatif, anak bisa meningkatkan serta mengumpulkan semua kemampuannya. Anak sering belajar dengan bermain dan melakukan berbagai eksplorasi pada objek-objek dan pengalaman. Anak bisa menumbuhkan pengetahuannya sendiri dengan interaksi sosial melalui orang-orang yang berada disekitarnya pada saat mereka memahaminya dengan bahasa dan gerakan sehingga membangun kognitif ke arah berpikir verbal. Salah satu bidang perkembangan yang perlu dikembangkan adalah aspek perkembangan bahasa.

Montessori dalam (Rosalina, n.d.) mengatakan bahwa perkembangan bahasa anak terlihat ketika anak memasuki usia empat tahun, yaitu ketika anak-anak giat belajar membaca dan menulis dengan antusias. Vygostsky dalam (Lestaningrum, 2014) juga mengatakan bahwa bahasa merupakan sentral yang sangat penting dalam proses belajar anak, dan dalam perkembangan bahasa berhubungan langsung terhadap perkembangan kognitif anak. Bahasa merupakan sistem simbolik untuk berkomunikasi yang disebut juga bahasa merupakan alat budaya.

Dalam penelitian Pebriana (2017) Suhartono mengatakan bahwa fungsi bahasa bagi anak usia dini sebagai sarana untuk berpikir, mendengarkan, berbicara, dan merupakan sarana untuk anak mampu membaca dan menulis. Kemampuan bahasa bukan saja dilihat dari kemampuan anak membaca, tetapi dilihat dari kemampuan lainnya seperti kemampuan dalam penguasaan kosa kata, kemampuan dan pemahaman komunikasi pada anak (Suryana, 2018). Kosakata merupakan sebuah komponen dalam bahasa yang terkait dengan pemakaian kata pada saat sesoarang berbahasa. Upaya meningkatkan perkembangan bahasa pada anak, dapat direalisasikan dengan melatih anak dalam mengembangkan kosakata yang dapat dimulai dari kosa kata yang ada dan dekat di sekitar lingkungan anak (Firdaus \& Muryanti, 2020).

Penguasaan perbendaharaan kosa kata dapat dikembangkan pada anak melalui aktivitas bermain, yang salah satunya adalah melalui permainan tradisonal. Dalam penelitian Ilhami et al (2019) bahwa permainan tradisional kuda berbisik dapat meningkatkan kemampauan perbendaharaan kosakata anak usia 5-6 tahun sebesar 64\%. Begitu juga dalam penelitian Arini \& Reza (2014) bahwa permainan tradisional ular naga dapat meningkatkan kosakata anak yaitu 3,58 anak mampu menyimpulkan 6-7 jawaban kata dan 3,05 anak mampu menyimpulkan 5-6 jawaban kata. Hal ini dapat disimpulkan bahwa melalui permainan tradisonal mampu meningkatkan kemampuan kosakata pada anak.

Gorys Keraf dalam (Irmawati \& Surahman, n.d.) mengatakan bahwa kosakata adalah unsur yang fundamental dalam bahasa dan memiliki peranan yang sangat penting untuk dikembangkan dan ditingkatkan pada kemampuan bahasa, yaitu bahasa verbal dan bahasa non verbal dalam mewujudkan gabungan dari pikiran dengan perasaan yang digunakan. Menurut Gleason dalam (Rahim \& Nurlailah, 2020) bahwa anak pada usia lima tahun sudah mampu menyusun kosa kata sebanyak 800 kata dengan menyusun beberapa kalimat seperti kalimat pertanyaan, kalimat negatif kalimat tunggal, kalimat majemuk serta anak juga mampu menggunakan bahasa pada situasi apapun. 
Menurut Brodin \& Renblad (2020) mengatakan bahwa penguasaan kosa kata dapat mempengaruhi keterampilan berbahasa seseorang, begitu juga sebaliknya bahwa kemampuan seseorang dalam menggunakan bahasa juga banyak dipengaruhi oleh kosakata yang dimilikinya. Begitu juga menurut Kurniawati et al (2016) bahwa kosakata adalah suatu kegiatan keterampilan atau kemampuan seseorang dalam memahami dan mengetahui penggunaan kata-kata yang terdapat dalam suatu bahasa baik bahasa secara lisan maupun dalam bentuk tulisan. Dengan demikian bahasa merupakan alat untuk komunikasi bagi seseorang untuk menyampaikan keinginan dan pendapat kepada orang lain baik secara lisan maupun tulisan, yang mana bahasa tersebut berfungsi apabila keterampilan berbahasa seseorang meningkat (Markus et al., 2018; Putri et al., 2019; Sari \& Suryana, 2019). Dan keterampilan berbahasa seseorang meningkat apabila kualitas dan kuantitas kosa katanya juga meningkat.

Permainan tradisonal merupakan permainan yang dimainkan oleh anak-anak zaman dahulu tanpa menggunakan alat modern seperti yang digunakan oleh anak-anak saat sekarang ini (Ilhami \& Khaironi, 2018). Sebagaimana yang disampaikan oleh Agustina \& Hafidz (2018) bahwa melalui permainan tradisonal akan memudahkan anak untuk memahami pembelajaran apa yang diberikan oleh gurunya. Salah satu permainan tradisional adalah permainan Pancasila Lima Dasar. Sebagaimana yang dikatakan oleh Witasari \& Wiyani (2020) permainan tradsional Pancasila lima dasar ini dimainkan secara berkelompok yang mana anak dilatih untuk berpikir menyebutkan nama-nama benda yang diawali dengan huruf vokal.

Menurut Agung \& Prawini (2017) bahwa permainan tradisonal pancasila lima dasar sangatlah efektif digunakan dalam proses pembelajaran dan mampu meningkatkan proses perkembangan kognitif pada anak. Sikap komunikatif anak ketika bermain pancasila lima dasar ini ikut terbentuk dan mengharuskan anak untuk berkomunikasi dengan teman yang lainnya. Selain itu, permainan tradisional ini juga dapat menanamkan jiwa nasionalisme pada anak didik.

Berkaitan dengan kemampuan kosa kata anak, permasalahan yang sering terlihat di Taman Kanak-Kanak bahwa anak masih kurang optimal dalam penguasaan kosa kata yang terlihat pada saat anak bercerita dengan mengekspresikan sesuai pikiran imajinasinya ketika mengarang cerita yang diberikan oleh gurunya. Begitu juga dalam tanya jawab anak masih ada anak yang belum mampu menjawab pertanyaan yang diberikan oleh guru serta kurang tepat dan kurang lancarnya anak mengucapkan kata. Berdasarkan hasil pengamatan tersebut, maka peneliti ingin melakukan penelitian dalam meningkatkan kemampuan kosakata anak melalui permainan tradisional Pancasila Lima Dasar. Perbedaan penelitian ini dengan sebelumnya adalah peneliti lebih memfokuskan pada kosa kata anak usia 5-6 tahun di TK Pembina Kandis Kabupaten Siak. Kosa kata yang digunakan tidak hanya nama-nama benda saja, melainkan kosa kata yang lebih luas lagi sesuai dengan tema-tema yang dipelajari anak. Selain itu juga, permainan pancasila lima dasar dibuat secara menarik, inovatif dan lebih interaktif.

\section{METODOLOGI}

Penelitian ini menggunakan penelitian kualitatif yaitu tindakan kelas (PTK) yang bertujuan untuk memperbaiki atau meningkatkan kosa kata pada anak anak usia dini melalui permainan tradisional pancasila lima dasar. Subjek pada penelitian ini adalah anak Kelompok B usia 5-6 tahun di TK Pembina Kandis Kabupaten Siak berjumlah 12 anak yang terdiri dari 7 perempuan dan 5 anak laki-laki Teknik pengumpulan data menggunakan observasi dan dokumentasi. Tahap-tahap pada penelitian ini terdiri dari perencanaan/persiapan tindakan, pelaksanaan tindakan, observasi dan refleksi. 


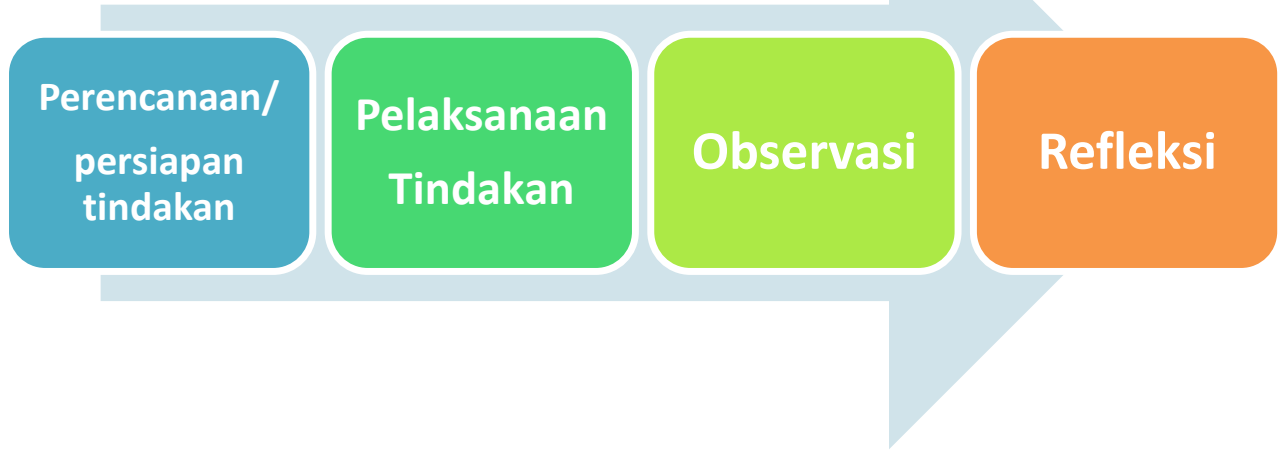

Gambar 1. Tahap-tahap Penelitian

Pelaksanaan penelitian ini dilakukan dua (2) siklus yang mana satu siklus dilakukan 3 tindakan/pertemuan. Analisis data yang digunakan untuk mengetahui peningkatan kosa kata pada anak usia dini melalui permainan tradsional pancasila lima dasar menggunakan rumus penilaian (Purwanto, n.d.). Berikut penjabarannya :

$$
\mathrm{NP}=\frac{R}{S M} X 100
$$

Keterangan :

$\mathrm{NP} \quad=$ nilai persen yang diharapkan

$\mathrm{R} \quad=$ skor mentah yang diperoleh anak

$\mathrm{SM}=$ skor maksimum ideal dari tes yang bersangkutan

$100=$ bilangan tetap

\section{HASIL DAN PEMBAHASAN}

Pada penelitian ini, peneliti menggunakan indikator yang terdapat pada Permendikbud Nomor 137 Tahun 2014 yaitu; 1) Menjawab pertanyaan yang lebih kompleks, 2) Menyebutkan kelompok gambar yang memiliki bunyi yang sama, 3) Menyebutkan kelompok gambar yang memiliki bunyi yang sama, 4) Memiliki perbendaharaan kata serta mengenal simbol-simbol untuk persiapan membaca, menulis dan berhitung, 5) Memiliki lebih banyak kata-kata untuk mengekpresikan ide pada orang lain. Penelitian ini dilaksanakan pada tanggal 2 September 2021 sampai dengan tanggal 28 September 2021 di kelompok B TK Pembina Kandis Kabupaten Siak.

\section{Deskripsi Pra Tindakan}

Peneliti melakukan pengamatan terhadap perkembangan penguasaan kosa kata pada tanggal 3 September 2021 disaat tema pembelajaran lingkunganku dengan sub tema sekolahku, yang merupakan sebagai langkah awal sebelum melakukan tindakan kelas. Pada tahap ini peneliti dan guru kolaboratif melakukan bimbingan dan stimulasi untuk mengoptimalkan penguasaan kosa kata pada anak. Instrument yang digunakan peneliti ialah indikator Permendikbud Nomor 137 Tahun 2014. Berdasarkan hasil pra tindakan pada menunjukkan bahwa masih perlunya stimulasi penguasaan kosa kata anak karena masih termasuk kategori belum berkembang (BB). Tabel 1 adalah hasil observasi penguasaan kosa kata pada anak yang diperoleh waktu pra tindakan.

Berdasarkan tabel 1 dapat dilihat kosa kata di kelompok B TK Pembina Kandis Kabupaten Siak sebelum dilakukan tindakan penelitian atau pra tindakan memiliki angka rata-rata sebesar 18,4 atau sebesar 38,33 \% dimana angka tersebut berada dalam kategori 
belum berkembang (BB). Dengan demikian peneliti merasa perlu melakukan tindakan penelitian kelas untuk meningkatkan kosa kata pada anak yang akan dilakukan melalui kegiatan permainan tradisonal pancasila lima dasar.

Tabel 1. Kosa Kata Anak Pra Tindakan

\begin{tabular}{|c|c|c|c|c|}
\hline \multirow[t]{2}{*}{ No } & \multirow[t]{2}{*}{ Indikator } & \multicolumn{2}{|c|}{ Skor } & \multirow[t]{2}{*}{ Presentase } \\
\hline & & Aktual & Ideal & \\
\hline 1 & Menjawab pertanyaan yang lebih kompleks & 23 & 48 & 47,92 \\
\hline 2 & $\begin{array}{l}\text { Menyebutkan kelompok gambar yang memiliki bunyi yang } \\
\text { sama }\end{array}$ & 21 & 48 & 43,75 \\
\hline 3 & $\begin{array}{l}\text { Menyebutkan kelompok gambar yang memiliki bunyi yang } \\
\text { sama }\end{array}$ & 18 & 48 & 37,50 \\
\hline 4 & $\begin{array}{l}\text { Memiliki perbendaharaan kata serta mengenal simbol- } \\
\text { simbol untuk persiapan membaca, menulis dan berhitung }\end{array}$ & 15 & 48 & 31,25 \\
\hline 5 & $\begin{array}{l}\text { Memiliki lebih banyak kata-kata untuk mengekpresikan ide } \\
\text { pada orang lain }\end{array}$ & 15 & 48 & 31,25 \\
\hline \multirow{2}{*}{\multicolumn{2}{|c|}{ Jumlah }} & 92 & 240 & 191,67 \\
\hline & & 18,4 & 48 & 38,33 \\
\hline
\end{tabular}

\section{Tindakan Siklus I}

Penelitian tindakan kelas pada Siklus I ini dilakukan sebanyak 3 (tiga) kali pertemuan yang dilakukan mulai dari tanggal 6 September 2021 sampai pada tanggal 16 September 2021. Gambar 2 merupakan tahapan tindakan siklus I, yaitu tahap menyusun RPP dan tahap pelaksanaan.

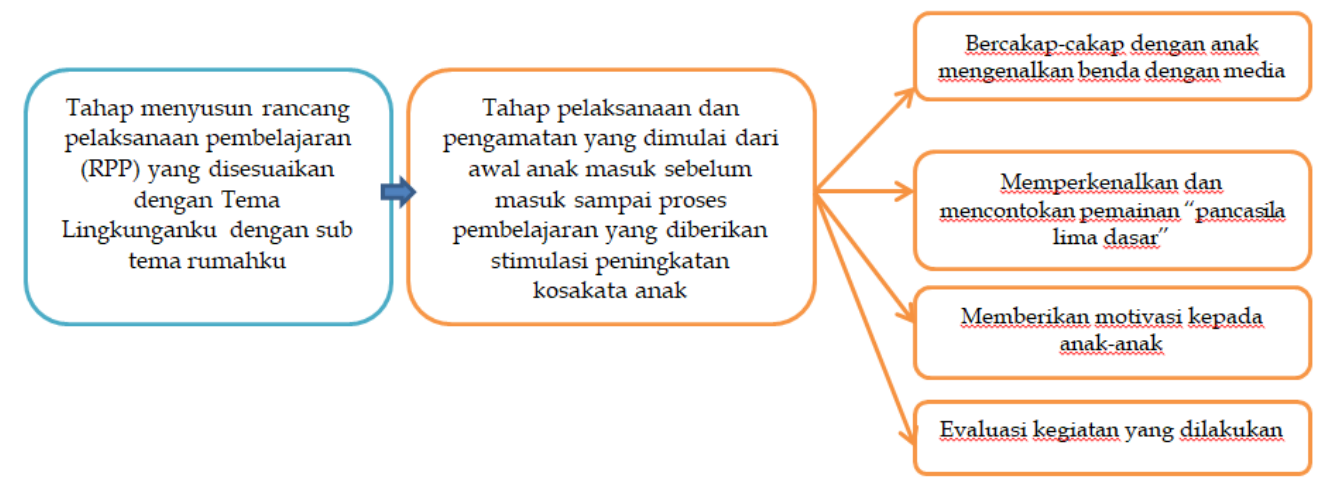

Gambar 2. Tahapan Tindakan Siklus I

Tindakan siklus I ini peneliti melakukan pengamatan terhadap kosa kata anak. Pada proses siklus I ini dilakukan tiga kali pertemuan berjalan lancar sesuai dengan perencanaan yang telah disiapkan. Adapun hasil pengamatan terhadap peningkatan kosa kata anak melalui permainan tradisonal pamcasila lima dasar dapat dilihat pada tabel 2.

Berdasarkan dari tabel 2, dapat disimpulkan bahwa persentase peningkatan kosa kata pada anak kelompk B TK Pembina Kandis Kabupaten Siak melalui permainan tradisonal pancasila lima dasar. Pada tiap pertemuan pada siklus I mengalami peningkatan disetiap pertemuan. Nilai yang diperoleh dari siklus adalah sebagai berikut; 1) Peretemuan 1 memiliki nilai sebesar 56,66 \% dengan kriteria mulai berkembang (MB), 2) Pertemuan ke 2 memiliki persentasi 59,16 \% masih dalam kategori mulai berkemban (MB), 3) Pertemuan ke 3 memiliki persentase sebesar 6,66 \% dengan kategori berkembang sesuai harapan (BSH). Untuk hasil rata-rata peningkatan kosa kata anak melalui permainan tradisional pancasila lima dasar pada siklus I mencapai nilai presentase sebesar 59,16 \%. Angka peningkatan kosa kata anak melalui permainan tradisional pancasila lima dasar pada akhir siklus I masih perlu ditingkatkan lagi dengan upaya pada siklus 2 . 
Tabel 2. Rekapitulasi Kosa Kata Anak Siklus I

\begin{tabular}{clcccc}
\hline No & \multicolumn{1}{c}{ Indikator } & $\begin{array}{c}\text { Pertemuan } \\
\mathbf{1}\end{array}$ & $\begin{array}{c}\text { Pertemuan } \\
\mathbf{2}\end{array}$ & $\begin{array}{c}\text { Pertemuan } \\
\mathbf{3}\end{array}$ & $\begin{array}{c}\text { Rata- } \\
\text { Rata }\end{array}$ \\
\hline $\mathbf{1}$ & $\begin{array}{l}\text { Menjawab pertanyaan yang lebih } \\
\text { kompleks }\end{array}$ & 56,25 & 60,42 & 64,58 & 60,417 \\
$\mathbf{2}$ & $\begin{array}{l}\text { Menyebutkan kelompok gambar yang } \\
\text { memiliki bunyi yang sama }\end{array}$ & 54,17 & 56,25 & 58,33 & 56,25 \\
$\mathbf{3}$ & $\begin{array}{l}\text { Menyebutkan kelompok gambar yang } \\
\text { memiliki bunyi yang sama kama serta }\end{array}$ & 60,42 & 60,42 & 62,5 & 61,113 \\
$\mathbf{4}$ & $\begin{array}{l}\text { Memiliki perbendaharaan kata } \\
\text { mengenal simbol-simbol untuk } \\
\text { persiapan membaca, menulis dan } \\
\text { berhitung }\end{array}$ & 58,33 & 60,42 & 57,64 \\
$\mathbf{5}$ & $\begin{array}{l}\text { Memiliki lebih banyak kata-kata untuk } \\
\text { mengekpresikan ide pada orang lain }\end{array}$ & 58,33 & 60,42 & 62,5 & 60,417 \\
\hline & Rata-Rata & 56,668 & 59,168 & 61,666 & 59,167 \\
\hline
\end{tabular}

\section{Tindakan Siklus II}

Pada siklus II peneliti dilaksanakan pada tanggal 20 sampai dengan tanggal 28 September 2021. Tindakan siklus II ini sama dengan siklus I dengan melakukan 3 kali pertemuan juga. Berdasarkan hasil observasi pada siklus I peneliti menyiapkan beberapa hal yaitu; 1) Menyusun rancangan pelaksanaan pembelajaran (RPP) yang disesuaikan dengan Tema Lingkunganku dengan subtema sekolahku sebagai acuan penyajian materi, 2) Melakukan koordinasi dengan guru sebagai kolaborator, menyiapkan lembaran observasi untuk mencatat segala aktivitas selama proses kegiatan belajar mengajar yang berisikan mencakup kegiatan anak bermain permainan tradisonal pancasila lima dasar, 3) Mempersiapkan kamera untuk mendokumentasikan proses pembelajaran dalam penelitian. Pelaksanaan dan pengamatan pengembangan kosa kata ini dilakukan sejak awal anak masuk sebelum mulainya proses pembelajaran kegiatan sampai pada kegiatan akhir pembelajaran. Namun pada tindakan siklus II ini peneliti merubah taktik bermain dengan membagi anak menjadi 2 kelompok dalam melakukan permainan tradisonal pancasila lima dasar ini, yang bertujuan untuk memberikan kesempatan kepada lebih banyak untuk mengungkapkan kata yang diketahuinya. Selama kegiatan peneliti mengobservasi dan mendokumentasikan kegiatan tersebut. Pada akhir kegiatan peneliti mengulang kembali tentang kegiatan yang telah dilakukan. Peneliti memberikan penghargaan berupa pujian kepada anak yang berani menjawab pertanyaan dengan tepat yang diberikan oleh peneliti dan guru.

Pada siklus II ini pertemuan 1, ke 2 dan ke 3 dilakukan pengamatan terhadap peningkatan kosa kata anak melalui permainan tradisonal pancasila lima dasar. Proses pembelajaran pada siklus II ini berjalan lancar dan berhasil sesui yang diharapakan. Hasil pengamatan pada siklus II menunjukkan adanyan peningkatan kosa kata anak melalui permainan tradisional pancasila lima dasar yang signifikan. Dari hasil observasi pada siklus II diperoleh data sebagaimana pada tabel 3.

Hasil observasi pada tabel 3 dapat disimpulkan bahwa penguasaan kosa kata pada anak kelompok B di TK Pembina Kandis Kabupaten Siak memiliki nilai rata-rata pada pertemuan 1 di siklus II yaitu sebesar $65,83 \%$ berada dalam kategori berkembang sesuai harapan (BSH), pertemuan ke 2 pada siklus II memiliki nilai rata-rata sebesar 78, 51 \% masih berada pada kategori berkembang sesuai harapan (BSH) dan pada pertemuan 3 silkus II memiliki nilai rata-rata sebesar 89,16 berada pada kategori berkembang sangat baik (BSB). Untuk hasil rata-rata peningkatan kosa kata anak pada siklus II mencapai nilai rata-rata sebesar 77, 83 \% berada pada kategori berkembang sesuai harapan (BSH). Peningkatan angka rata-rata kosa kata pada anak kelompok B di TK Pembina Kandis Kabupatens Siak pada pertemuan kali ini sudah baik, maka penelitian tindakan kelas tidak memerlukan tindakan refleksi dan penelitian sudah dianggap selesai. 
Tabel 3. Rekapitulasi Kosa Kata Anak Siklus II

\begin{tabular}{lllcccc}
\hline No & \multicolumn{1}{c}{ Indikator } & Pertemuan 1 & $\begin{array}{c}\text { Pertemuan } \\
\mathbf{2}\end{array}$ & $\begin{array}{c}\text { Pertemuan } \\
\mathbf{3}\end{array}$ & $\begin{array}{c}\text { Rata- } \\
\text { Rata }\end{array}$ \\
\hline $\mathbf{1}$ & $\begin{array}{l}\text { Menjawab pertanyaan yang lebih } \\
\text { kompleks }\end{array}$ & 70,83 & 81,25 & 91,67 & 81,25 \\
$\mathbf{2}$ & $\begin{array}{l}\text { Menyebutkan kelompok gambar yang } \\
\text { memiliki bunyi yang sama }\end{array}$ & 64,58 & 77,08 & 89,58 & 77,08 \\
$\mathbf{3}$ & $\begin{array}{l}\text { Menyebutkan kelompok gambar yang } \\
\text { memiliki bunyi yang sama }\end{array}$ & 66,67 & 79,17 & 91,67 & 79,17 \\
$\mathbf{4}$ & $\begin{array}{l}\text { Memiliki perbendaharaan kata serta } \\
\text { mengenal simbol-simbol untuk } \\
\text { persiapan membaca, menulis dan } \\
\text { berhitung }\end{array}$ & 62,5 & 77,98 & 87,5 & 75,993 \\
$\mathbf{2}$ & & & & \\
\hline & $\begin{array}{l}\text { Memiliki lebih banyak kata-kata untuk } \\
\text { mengekpresikan ide pada orang lain }\end{array}$ & 64,58 & 77,08 & 85,42 & 75,693 \\
\hline
\end{tabular}

Berdasarkan dari tabel siklus I dan tabel siklus II dapat dilihat peningkatan kosa kata pada anak kelompok B di TK Pembina Kabupaten Siak dengan melakukan tindakan kelas melalui permainan tradisional pancasila lima dasar. Untuk lebih jelasnya peningkatan kosa kata pada anak kelompk B di TK Pembina Kandis Kabupaten Siak dapat dilihat melalui grafik pada gambar 3.

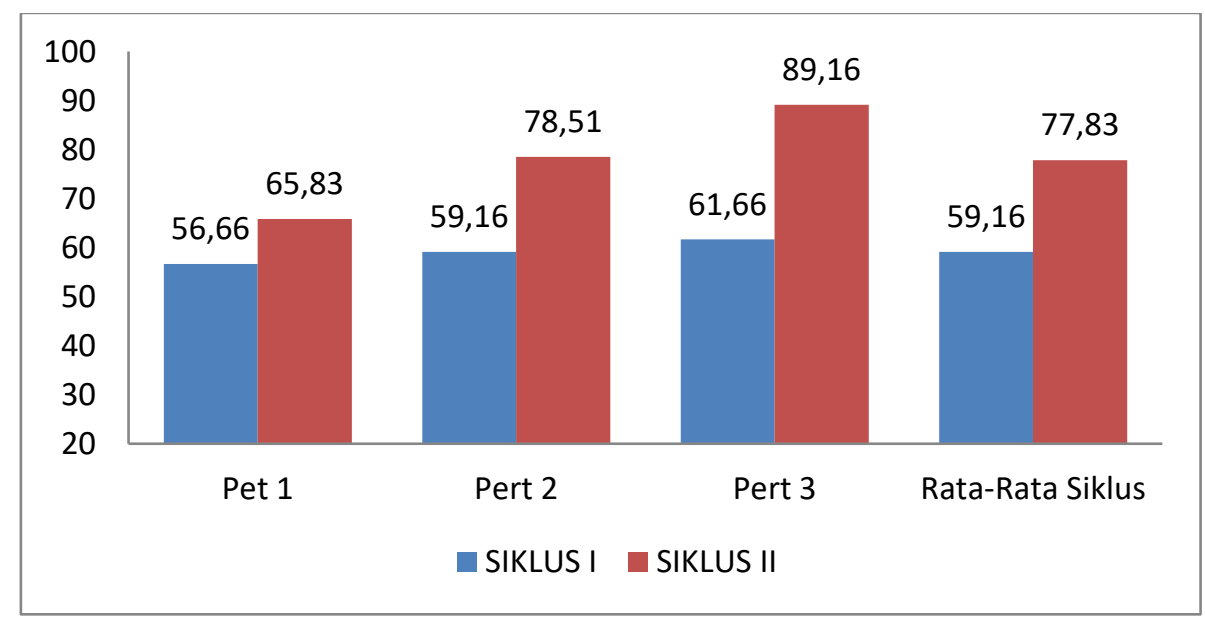

\section{Gambar 3. Grafik Perbandingan Peningkatan Kosa Kata Pada Siklus I dan Siklus II Analisis Data}

Hasil analisis data dalam peningakatan kosa kata pada anak kelompok B di TK Pembina Kandis Kabupaten Siak melalui permainan tradisional pancasila lima dasar dapat dilihat dari perbandingan perolehan pembelajaran pada anak dan terlihat pada prsentasi ketuntasan belajar anak yang dimulai dari siklus I dan siklus II. Hal ini dapat dilihat pada tabel 4 .

Berdasarkan dari tabel 4 dapat dilihat adanya peningkatan kosa kata anak melalui permainan tradisional pancasila lima dasar. Dari tabel di atas dapat diuraikan bahwa pada setiap indikator mengalami peningkatan bahwa prensetasi saat pra tindakan 38,33\% masuk pada kategori belum berkembang (BB), pada siklus I nilai rata-rata sebesar 59, 16 \% berada dalam kategori mulai berkembang (MB), dan pada siklus II diperoleh nilai rata-rata sebesar 77, $83 \%$ berada pada kategori berkembang sesuai harapan (BSH). Hal tersebut dapat 
dijelaskan adanya peningkatan kosa kata pada anak melalui permainan tradisonal pancasila lima dasar yang lebih jelas lagi dapat dilihat pada diagram batangan pada gambar 4 .

\section{Tabel 4. Rekapitulasi Pra Siklus, Siklus I dan Siklu II}

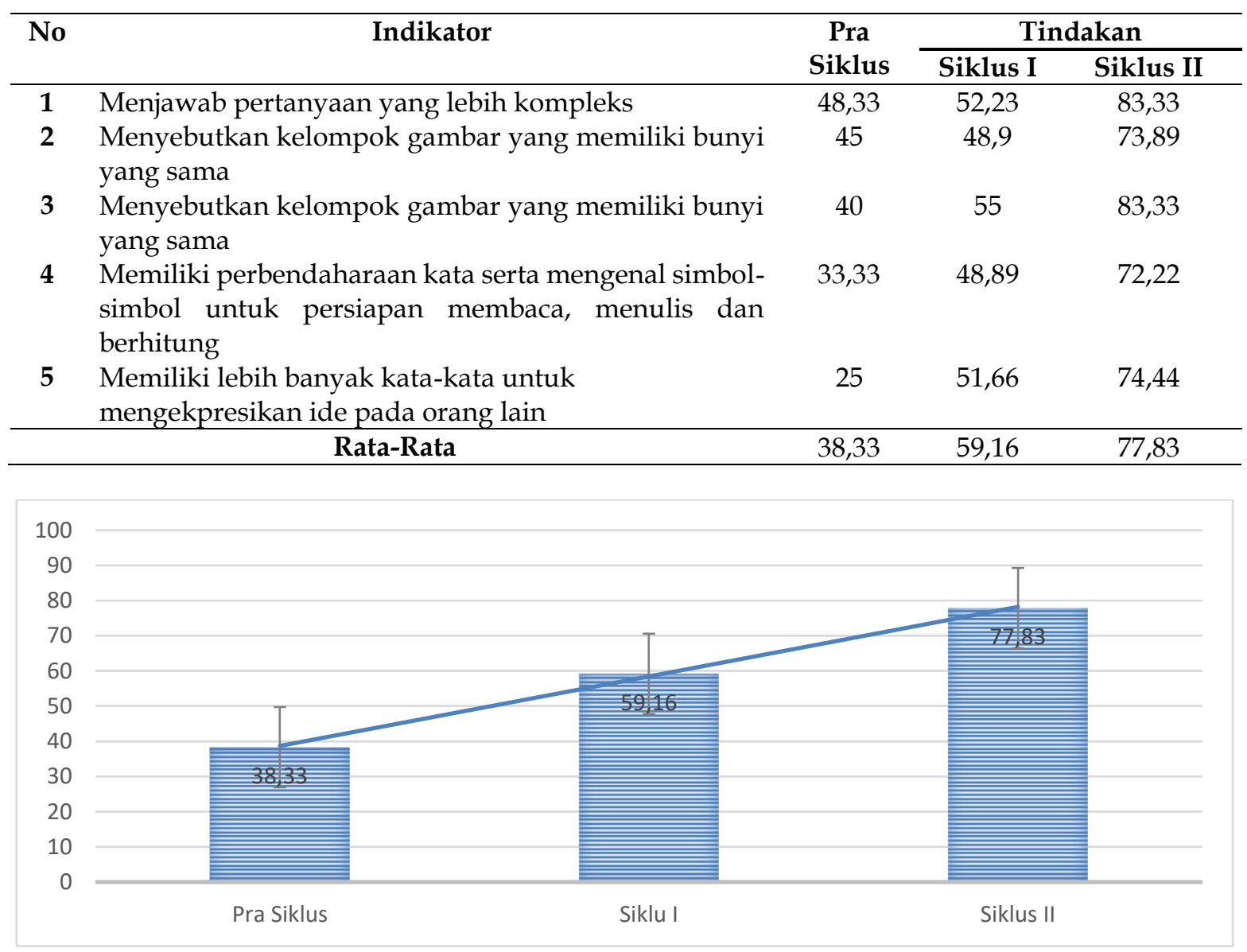

Gambar 4. Peningkatan Kemampuan Kosa Kata Pada Anak

Perkembangan bahasa anak dapat berkembang melalui stimulasi. Salah satu stimulasi yang dapat membantu perkembangan bahasa anak adalah melalui permainan. Dalam penelitian Winarti \& Suryana, (2020) perkembangan bahasa anak dapat berkembang melalui permainan puppet fun, melalui permainan ini mampu meningkatkan perkembangan bahasa yaitu kemampuan membaca anak. Hal ini sejalan dengan penelitian (Rahayu \& Brantasari, 2019) bahwa permainan dapat meningkatkan perkembangan bahasa anak, hasil penelitian yang dilakukan menunjukkan bahwa permainan melalui media kartu dapat mengembangkan bahasa anak. Berbeda dengan hasil penelitian Trimantara \& Mulya, (2019) bahwa melalui permainan puzzle perkembangan bahasa anak belum berkembang dengan maksimal. Hasil penelitian menunjukkan bahwa 15 dari 5 orang anak kategori belum berkembang, 8 anak kategori Mulai berkembang, 2 orang anak kategori berkembang sesuai harapan. Faktor penyebab tidak berkembangnya bahasa anak adalah tidak ada implemetasi langkah-langkah bermain puzzle secara keseluruhan.

Mengembangkan perkembangan bahasa anak melalui permainan sebaiknya dijelaskan secara struktur, dan penggunaan kalimat yang baik dan mudah dipahami oleh anak, khususnya mengingkatkan kosa kata anak. Kosa kata anak dapat meningkat jika pendidik atau orang tua menggunakan pembelajaran atau stimulasi yang tepat dan menarik bagi anak (Chen \& Chan, 2019; Hansen \& Broekhuizen, 2021). Salah satu stimulasi yang dapat dikembangkan melalui permainan tradisional (Junaedah et al., 2020; Pic et al., 2019). 
Berdasarkan hasil penelitian tentang penguasaan kosa kata pada anak usia dini melalui permainan tradisonal pancasila lima dasar terjadi peningkatan pemahaman dalam penguasaan kosa kata. Dalam hal ini penguasaan kosa kata pada anak sudah lebih baik dari sebelum menggunakan permainan tradisional pencasila lima dasar. Pada permainan tradisional ini anak dapat mengenalkan kosa kata yang baru. Hasil penelitian yang dilakukan peneliti memiliki persamaan pada hasil penelitian Ilhami et al., (2019) bahwa permainan tradisonal kuda bisik mampu menambah kosa kata anak usia 5-6 tahun ditunjukkan bahwa hasil tes pembendaharaan kosa kata anak $36 \%$ berkembang sesuai harapan dan $64 \%$ anak berkembang sangat baik. Sejalan dengan penelitian Roswati, (2020) bahwa permainan chinese whispers mamou meningkatkan kosa kata dan memperoleh kosa kata baru pada anak. Adapun persamaan penelitian yang dilakukan Witasari \& Wiyani, (2020) adalah permainan tradisonal dapat meningkatkan perkembangan anak, hanya saja perbedaan dari penelitian ini adalah peneliti meningkatkan kosa kata sedangkan Witasari \& Wiyani, (2020) mengembangkan karakter anak usia dini.

Permainan tradisonal pancasila lima dasar ini, anak diminta harus menyebutkan kosa kata yang berbeda dengan temannya. Pada permainan tradisonal pancasila lima dasar ini, dapat mengenalkan berbagai kelompok nama-nama benda. Permainan ini juga dapat menjadi strategi pembelajaran untuk mengenalkan sesuatu tema tertentu seperti sub tema buahbuahan. Dengan demikian dapat disimpulkan permainan tradisional pancasila lima dasar dapat mengembangkan penguasaan kosa kata pada anak usia dini. Sehingga melalui kosa kata yang bervariasi dapat meningkatkan kecerdasan anak dalam berbahasa.

\section{SIMPULAN}

Permainan tradisonal sangatlah penting dikenalkan pada anak, terlebih permainan tradisonal ini berkaitan dengan lambang Negara yang akan menumbuhkan jiwa nasionalisme sejak dini pada anak. Berdasarkan hasil penelitian yang dilakukan bahwa permainan pancasila lima dasar ini merupakan permainan yang dapat meningkatkan kosa kata anak. Selain itu metode permainan pancasila lima dasar sangat efektif, inovatif, interaktif dan menyenangkan. Kosa kata yang diperkenalkan pada permainan ini berkaitan dengan tematema yang ada di Taman Kanak-kanak. Permainan ini menjadi strategi yang baik untuk mengembangkan aspek perkembangan anak usia dini yang lain, seperti: Kognitif, socialemosional, fisik motoric, nilai agama moral, dan lain-lain.

\section{UCAPAN TERIMAKASIH}

Peneliti mengucapkan terima kasih kepada pihak terkait. Terutama TK Pembina Kandis Kabupaten Siak yang memberikan waktu dan kesempatan untuk melakukan penelitian ini. Peneliti berharap semoga hasil penelitian ini bermanfaat bagi bidang Pendidikan Anak Usia Dini.

\section{DAFTAR PUSTAKA}

Agung, A. A. G., \& Prawini, I. G. A. P. (2017). Efektivitas Aktivitas Pembelajaran Mengomunikasikan Berbasis Permainan Tradisional Terhadap Dimensi Proses Kognitif. International Journal of Elementary Education., 1, 180-188. https://doi.org/10.23887/ijee.v1i3.10324

Agustina, Y., \& Hafidz, I. P. (2018). Optimalisasi Media Permainan Kartu Abaca Untuk Meningkatkan Kemampuan Membaca Dini Pada Kelompok B Tk Al-Hasaniyah Nw Jenggik. 01(2), 75-81. https://doi.org/10.29408/goldenage.v1i02.558

Arini, A., \& Reza, M. (2014). Pengembangan Permainan Ular Naga Modifikasi Untuk Meningkatkan Penguasaan Kosakata. Paper Knowledge . Toward a Media History of Documents, 3(3), 1-7. 
Brodin, J., \& Renblad, K. (2020). Improvement of preschool children's speech and language skills. Early Child Development and Care, 190(14), 2205-2213. https:// doi.org/10.1080/03004430.2018.1564917

Chen, R. W., \& Chan, K. K. (2019). Using Augmented Reality Flashcards to Learn Vocabulary in Early Childhood Education. Journal of Educational Computing Research, 57(7), 1812-1831. https://doi.org/10.1177/0735633119854028

Firdaus, M., \& Muryanti, E. (2020). View of Games Edukasi Bahasa Inggris untuk Pengembangan Kosakata Bahasa Inggris pada Anak Usia Dini. Pendidikan Anak Usi Dini, 4(2).

Hansen, J. E., \& Broekhuizen, M. L. (2021). Quality of the Language-Learning Environment and Vocabulary Development in Early Childhood. Scandinavian Journal of Educational Research, 65(2), 302-317. https://doi.org/10.1080/00313831.2019.1705894

Ilhami, B. S., Fitri, B. F. H., \& Ramdhani, S. (2019a). Permainan Kuda Bisik Untuk Meningkatkan Kemampuan Pembendaharaan Kosakata Anak Usia 5-6 Tahun. Cakrawala Dini: Jurnal Pendidikan Anak Usia Dini, 10(2), 101-108. https://doi.org/10.17509/cd.v10i2.19866

Ilhami, B. S., Fitri, B. F. H., \& Ramdhani, S. (2019b). Permainan Kuda Bisik Untuk Meningkatkan Kemampuan Pembendaharaan Kosakata Anak Usia 5-6 Tahun. Cakrawala Dini: Jurnal Pendidikan Anak Usia Dini, 10(2), 101-108. https://doi.org/10.17509/cd.v10i2.19866

Ilhami, B. S., \& Khaironi, M. (2018). Pelaksanaan Joyfull Learning Berbasis Permainan Tradisional Sasak Untuk Meningkatkan Motorik Kasar Anak Usia 5-6 Tahun. Jurnal Golden Age, 2(02), 59. https:// doi.org/10.29408/goldenage.v2i02.1023

Irmawati, H., \& Surahman, S. (n.d.). Pengaruh Aktivitas Media Wayang Kartun Terhadap Kemampuan Kosa Kata Anak Usia Dini. Anak Usia Dini, 10. http://journal.upgris.ac.id/index.php/paudia/article/view/8532/pdf

Junaedah, J., Thalib, S. B., \& Ahmad, M. A. (2020). The Outdoor Learning Modules Based on Traditional Games in Improving Prosocial Behaviour of Early Childhood. International Education Studies, 13(10), 88. https:// doi.org/10.5539/ies.v13n10p88

Kurniawati, C. H., Arini, N. W., \& Suarjana, M. (2016). Penerapan Model Pembelajaran Inside Outside Circle Untuk Meningkatkan Keterampilan Berbicara. PGSD Universitas Pendidikan Ganesha, 4(1), 10. https:// doi.org/10.33578/jpfkip.v10i2.8250

Lestaningrum, A. W. I. P. (2014). Meningkatkan Kemampuan Berbahasa Anak Usia Dini Melalui Media Panggung Boneka Tangan. Nusantara of Research, 1(01), 1-90.

Markus, N., Kusmiyati, K., \& Sucipto, S. (2018). Penguasaan Kosakata Bahasa Indonesia Anak Usia 4-5 Tahun. Fonema, 4(2), 102-115. https:// doi.org/10.25139/fonema.v4i2.762

Pebriana, P. H. (2017). Analisis Kemampuan Berbahasa dan Penanaman Moral Pada Anak Usia Dini Melalui Metode Mendongeng. Jurnal Obsesi : Journal of Early Childhood Education, 1(2), 139-147. https:// doi.org/10.31004/obsesi.v1i2.34

Pic, M., Lavega-Burgués, P., \& March-Llanes, J. (2019). Motor behaviour through traditional $\begin{array}{llll}\text { games. } & \text { Educational } & \text { 742-755. }\end{array}$ https:// doi.org/10.1080/03055698.2018.1516630

Purwanto, N. (n.d.). Prinsip-prinsip \& Teknik Evaluasi Pengajaran. PT Remaja Rosdkarya.

Putri, M., Rakimahwati, R., \& Zulminiati, Z. (2019). Efektivitas Penerapan Metode Bermain Peran Makro terhadap Perkembangan Bahasa Lisan Anak di Taman Kanak-kanak Darul Falah Kota Padang. Jurnal Ilmiah POTENSIA, 4(1), 49-58. https://doi.org/10.33369/jip.4.1.49-58

Rahayu, T.-, \& Brantasari, M.-. (2019). Peningkatan Kemampuan Berbahasa Anak Usia 5-6 Tahun Melalui Permainan Media Kartu Huruf Bergambar Di Tk Pelangi Tenggarong Seberang Tahun Pembelajaran 2016-2017. Jurnal Warna: Pendidikan Dan Pembelajaran Anak Usia Dini, 4(1), 39-51. https:/ / doi.org/10.24903/jw.v4i1.327 
Rahim, W., \& Nurlailah. (2020). Peningkatan Kemampuan Mengenal Huruf Vokal dan Huruf Konsonan Melalui Media Kartu Huruf Pada Anak Usia Dini Kelompok B KB Puncak Mewatang Kecamatan Bungin Kabupaten Enrekang. Jurnal Al-Athfal, 3(1). https://doi.org/10.15642/jeced.v1i1.501

Rosalina, A. (n.d.). Peningkatan Kemampuan Bahasa Anak Usia Dini Melalui Kegiatan Bermain. Psycho Idea, 1, 19-35.

Roswati, E. (2020). Meningkatkan Kosakata Anak Usia Dini Melalui Permainan Chinese Whispers. Jurnal PG-PAUD Trunojoyo: Jurnal Pendidikan Dan Pembelajaran Anak Usia Dini, 7(1), 32-36. https:// doi.org/10.21107/pgpaudtrunojoyo.v7i1.6420

Sari, N. E., \& Suryana, D. (2019). Thematic Pop-Up Book as a Learning Media for Early Childhood Language Development. JPUD - Jurnal Pendidikan Usia Dini, 13(1), 43-57. https://doi.org/10.21009/10.21009/JPUD.131.04

Suryana, D. (2013). Pendidikan Anak Usia Dini (Teori dan Praktik Pembelajaran). Padang: UNP Press Padang.

Suryana, D. (2018). Pendidikan Anak Usia Dini: Stimulasi \& Aspek perkembangan Anak. Prenada Group.

Suryana, D., \& Pd, M. (2014). Hakikat Anak Usia Dini. Dasar-Dasar Pendidikan TK, 1-65.

Trimantara, H., \& Mulya, N. (2019). Mengembangkan Bahasa Anak Usia 4-5 Tahun Melalui Alat Permainan Edukatif Puzzle. Al-Athfaal: Jurnal Ilmiah Pendidikan Anak Usia Dini, 2(1), 25-34. https://doi.org/10.24042/ajipaud.v2i1.4553

Winarti, W., \& Suryana, D. (2020). Pengaruh Permainan Puppet Fun terhadap Kemampuan Membaca Anak Usia Dini. Jurnal Obsesi : Jurnal Pendidikan Anak Usia Dini, 4(2), 873. https://doi.org/10.31004/obsesi.v4i2.462

Witasari, O., \& Wiyani, N. A. (2020). Permainan Tradisional untuk Membentuk Karakter Anak Usia Dini. JECED : Journal of Early Childhood Education and Development, 2(1), 5263. https:// doi.org/10.15642/jeced.v2i1.567 